\section{I de beste familier ...}

Skartveit G

\section{Den usynlege smerta}

Om rus og pårørande. 288 s. Oslo: Det norske samlaget, 2010. Pris NOK 349

ISBN 978-82-521-7613-1

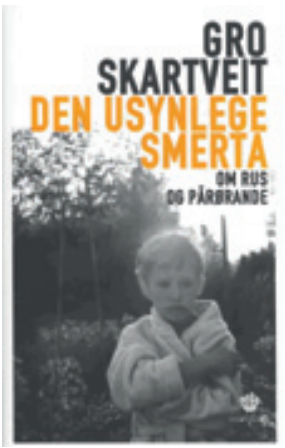

Den første, og

største, delen

består av «historier

fra virkeligheten»,

omtrent slik vi

fortsatt kan lese

dem i enkelte uke-

blad. Selv for en

forholdsvis garvet

rusterapeut ble det

i meste laget. Jeg

spurte stadig meg selv om det var

nødvendig å ta med så mange begredelige detaljer. Men så slo det meg at kanskje de som kjenner dette på kroppen, de pårørende selv, liker å lese om det - at det gir en slags fellesskapsfølelse å kunne nikke gjenkjennende til tragiske og dramatiske skildringer av de ruspårørendes turbulente og utrygge hverdag. Derfor ønsker jeg å overlate til andre lesere å vurdere om elendighetsdosen her ble for høy.

Boken er skrevet av en fagperson som også er politiker, og som derfor er programforpliktet til å komme med noen prinsipper og løsningsforslag. Her synes jeg Gro Skartveit gjør en god jobb. Det som går som en rød tråd gjennom alle beretningene, og som utkrystalliseres i flere av de ti rådene til pårørende hun gir mot slutten, er hvor lett det er å tro at man hjelper misbrukeren ut av misbruket, mens man i virkeligheten bidrar til fortsatt misbruk. Det dreier seg om noe så enkelt som å sette grenser og kunne si nei. Men vis meg den moren som gang på gang greier å avvise sin lidende og sterkt appellerende voksne sønn, det skal det mye mot og styrke til!

For meg som er opptatt av at rusvernet i Norge allerede er blitt altfor medikalisert, er perspektivet her kjærkomment. Forfatteren viser tydelig at rusproblemer, ikke minst sett med de pårørendes øyne, først og fremst er atferdsproblemer; uakseptabel oppførsel, kriminalitet, manglende kontroll og tillitsbrudd. Her er det ofte vel så hensiktsmessig å søke hjelp hos politiet som hos legen, og det står mye om politi. Derfor undres jeg litt over den makten og myndig- heten sosionomen Gro Skartveit mener legene har på rusfeltet. Det at noen leger skriver ut piller i øst og vest er selvsagt et stort problem som ødelegger for alle, men jeg tror neppe russituasjonen i Norge ville endret seg vesentlig om vi fikk stoppet disse tankeløse legene. Og som seriøs rusterapeut er vel legen neppe bedre enn andre fagpersoner - det finnes ingen mirakelkur.

Det fine er at man ikke presenterer substitusjonsbehandling (metadon, buprenorfen og ev. heroinutdeling) som det viktigste og saliggjørende tiltaket. Her skiller politikeren Gro Skartveit seg fra de fleste av sine kolleger. Hun kjenner feltet godt nok til å vite at slik behandling er og blir en nødløsning.

Boken vil være en god støtte for alle som trenger hjelp til å etablere et eget liv i nærheten av en rusmisbruker.

\section{Olaf Gjerløw Aasland}

Legeforeningens forskningsinstitutt

\section{Forbilledlig om nevrologi og pedagogikk}

Rønhovde LI.

\section{... og noen går det trill rundt for!}

Om hjernen, tenåringer og pedagogisk praksis. 243 s, tab, ill. Oslo: Gyldendal Akademisk, 2010. Pris NOK 350

ISBN 978-82-05-39571-8

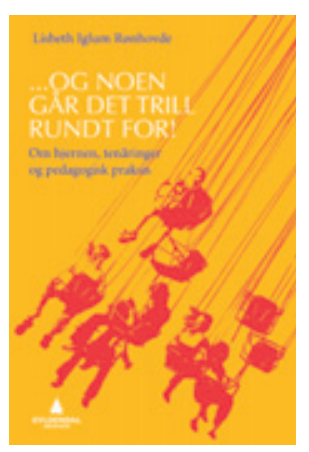

Forfatteren er universitetsutdannet spesialpedagog og arbeider til daglig i den kommunale pedagogisk-psykologiske rådgivertjenesten for barn og ungdom. Rønhovde henvender seg primært til fagfolk som arbeider i eller opp mot skoleverket. Hun forsøker å se daglige pedagogisk-psykologiske utfordringer i lys av moderne nevrobiologisk kunnskap om hjernen og dens utvikling hos barn og unge. Spesielt legger hun vekt på de nevrologiske forutsetningene for kognisjon og emosjoner, atferd og læring på ulike alderstrinn. Hun sier selv i innledningen at «boken handler om ungdomshjernen på den ene siden, pedagogisk virksomhet på den andre og hvordan samspillet mellom disse to kan videreutvikle møtet og forståelsen mellom ungdom, lærere og foresatte [...] Boken tar opp nyere forskning på og forståelse av tenåringers nevrologiske modning og utvikling. Denne forståelsen settes opp mot de formelle og uformelle, akademiske og sosiale krav som stilles til ungdomsgruppen.»

Boken er inndelt $i$ to hovedbolker: først hjernen og nevrokognitiv normalutvikling, deretter pedagogiske tiltak i et skoleperspektiv. Hovedkapitlene heter: Ungdom tabloid, Hjernen og ungdomshjernen, Fokus på tenåringselever og deres behov, Skolen i et organisasjons- og systemperspektiv, Ungdom er nesten barn, ikke nesten voksne. Illustrasjonene, vignettene og de små kasuistikkene er instruktive, og i tillegg finner man punktvise oppsummeringer av pedagogiske og kliniske poenger.

Ungdommers mangelfulle evne til å tilbakeholde impulser, deres ufullstendig utviklede frontallappsfunksjoner og svikt i «egenadministrasjon», liten evne til å «lese andre», forstå intensjoner og tolke ansiktsuttrykk og følelser er i vesentlig grad biologisk betinget. Forfatterens budskap er at elementær kjennskap til nevrologiske og nevropsykologiske utviklings- og modningsprosesser i ungdomsårene gir utdypet forståelse for hva som kan komme til nytte når man som sakkyndig skal tilrettelegge tiltak, gi råd, håndtere vanskelige situasjoner og ikke minst forebygge videre skjevutvikling og patologi.

Forfatteren er klar over at man ikke kan ekstrapolere kritikkløst fra nevrologisk forsknings stadig skiftende funn og perspektiver, og overføre dette direkte til hverdagen i klasserommet. Det er like galt å ignorere nevrobiologisk kunnskap hentet fra laboratoriene, som å applisere denne ukritisk inn i det levde liv. For en pedagog vil det likevel være av betydning å vite at det hjelper lite å bombardere en elev med fakta, hvis elevens kapasitet for å huske enkeltelementer, arbeidsminnet, ennå ikke kan ventes å være tilstrekkelig modnet. For en kliniker i pedagogisk-psykologisk rådgivertjeneste vil det på samme måte være viktig å vite hva man normalt bør kunne forvente av en ungdom på det trinn vedkommende er, når man skal vurdere alvorlighetsgrad, ulike tiltak og prognostikk.

Boken er pedagogisk forbilledlig (!) og 